\title{
Evaluasi Bahan Pakan Hasil Samping Industri Pertanian Berdasarkan Parameter Fermentabilitas Ruminal secara In Vitro
}

\author{
Evaluation of Feedstuffs from Agriculture Industry by-Product Based on Ruminal \\ Fermentability Parameter in In Vitro
}

\author{
E. Susilo, L. K. Nuswantara, dan E. Pangestu
}

Fakultas Peternakan dan Pertaniaan, Universitas Diponegoro

J1. Prof.Soedarto, SH Tembalang 50275, Semarang, Jawa Tengah Indonesia

Corresponding email: susiloeko851@gmail.com

\begin{abstract}
By-product of agriculture industries potentially are used in ruminant feed. However, utilization of nutrient content of by-product agriculture industries are needed to be evaluated on rumen fermentability. This study was conducted to evaluate ruminal fermentability of by-product of agriculture industries. Completely randomized design was used in the study, with 7 treatments and 3 replications. Corncob (T1), coffee hus (T2), onggok (T3), soybean meal (T4), palm kernel meal (T5), coconut meal (T6) and soybean curd waste (T7) were used in this study. Fistulated Etawah crossbreed goat was used for rumen fluid donor. Concentrations of acetate, propionate, butyrate, methane, ammonia and adenosine triphosphate were tested in this study. Data were analyzed using ANOVA and continued by Duncan test. The results were showed that by-product of agriculture industries were resulted a significant different $(\mathrm{P}<0.05)$ on concentration of acetate, propionate, butyrate, methane, ammonia and adenosine triphosphate. In conclusion, corncob has resulted the highest concentrations of acetate, propionate, butyrate and adenosine triphosphate. However, corncob also has resulted the highest methane concentration among all the by-product industries. The highest ammonia concentration was obtained on coconut meal and soybean meal.
\end{abstract}

Key words: by-product agriculture, fermentability, in vitro

\begin{abstract}
ABSTRAK
Bahan pakan dari hasil samping industri pertanian sangat potensial untuk dimanfaatkan sebagai pakan ruminansia, namun nilai nutriennya belum banyak dikaji. Penelitian bertujuan mengevaluasi bahan pakan hasil samping industri pertanian terhadap fermentabilitas ruminal secara in vitro. Penelitian ini menggunakan rancangan acak lengkap dengan 7 perlakuan dan 3 ulangan. Perlakuan terdiri atas janggel jagung, kulit kopi, onggok, bungkil kedelai, bungkil kelapa sawit, bungkil kelapa dan ampas tahu. Cairan rumen berasal dari kambing PE berfistula dengan pakan standar protein kasar 12\% dan TDN 62\%. Parameter yang diukur adalah konsentrasi asetat, propionat, butirat, konsentrasi metan, amonia dan adenosin triphosphate. Data dianalisis ANOVA dan dilanjutkan uji jarak berganda Duncan. Hasil analisis menunjukan perlakuan bahan pakan hasil samping industri pertanian berbeda nyata $(\mathrm{P}<0,05)$ terhadap konsentrasi asetat, propionat, butirat, konsentrasi metan, konsentrasi amonia dan adenosine triphosphate. Kesimpulannya, janggel jagung menghasilkan konsentrasi asetat, propionat, butirat dan adenosin triphosphate tertinggi. Namun, janggel jagung juga menghasilkan konsentrasi metan tertinggi. Konsentrasi amonia tertinggi diperoleh pada bungkil kelapa sawit dan diikuti bungkil kedelai.
\end{abstract}

Kata kunci: fermentabilitas, hasil samping industri pertanian, in vitro

\section{PENDAHULUAN}

Ketersediaaan bahan pakan dari segi kualitas, kuantitas dan kontinuitas merupakan faktor penting untuk mendukung produksi ternak ruminansia. Salah satu upaya untuk memenuhi ketersediaan pakan dapat dilakukan dengan mencari bahan pakan alternatif, yang relatif murah dan tidak bersaing dengan kebutuhan manusia. Pakan alternatif terutama banyak diperoleh darihasil samping industri pertanian. Bahan pakan hasil samping industri pertaniansangat potensial untuk mendukung pemenuhan 
kebutuhan pakan ternak, baik sebagai sumber energi dan protein. Bahan pakan alternatif berupa janggel jagung, kulit kopi, onggok, bungkil kelapa, bungkil kelapa sawit, bungkil kedelai dan ampas tahu adalah produk hasil samping industri pertanian yang mulai populer dimanfaatkan sebagai pakan ruminansia. Fachiroh et al.(2012), menyatakan bahwa pakan komplit dapat disusun dari bahan campuran hasil samping industri yang belum dimanfaatkan optimal sehingga ternak tidak perlu diberi hijauan. Pakan komplit berbahan hasil samping industri pertanian merupakan salah satu alternatif pemecahan masalah ketersediaan bahan pakan untuk ruminansia (Purbowati et al.,2007).

Ruminansia memiliki kekhasan pada proses pencernaan nutrien pakan yaitu adanya aktivitas fermentasi oleh mikrobia di dalam rumen. Salah satu faktor yang mempengaruhi produktivitas ternak ruminansia adalah fermentabilitas pakan akibat adanya aktivitas mikroba di dalam rumen (Hapsari et al., 2018). Aktivitas fermentasi oleh mikroba rumen merupakan upaya mikroba rumen untuk memperoleh energi, sumber karbon dan nitrogen guna perkembangbiakannya (Van Soest, 1994; van Houtert, 1993). Produk fermentasi karbohidrat dan protein pakan oleh mikroba rumen adalah volatile fatty acids (VFA), karbon dioksida $\left(\mathrm{CO}_{2}\right)$, hidrogen $\left(\mathrm{H}_{2}\right)$, air $\left(\mathrm{H}_{2} \mathrm{O}\right)$, metan $\left(\mathrm{CH}_{4}\right)$ dan amonia $\left(\mathrm{NH}_{3}\right)$ (Vlaming, 2008). Proses pembentukan asam asetat dan butirat menghasilkan $\mathrm{H}_{2}$ dan $\mathrm{CO}_{2}$ yang kemudian digunakan oleh bakteri metanogenik dalam pembentukan $\mathrm{CH}_{4}$. Semakin tinggi asam asetat dan butirat, maka semakin tinggi $\mathrm{CH}_{4}$ yang dihasilkan (Hapsari et al., 2018). Asam piruvat kemudian diubah menjadi VFA yang berupa asetat, propionat dan butirat, selain itu juga menghasilkan karbondioksida $\left(\mathrm{CO}_{2}\right), \mathrm{H}_{2} \mathrm{O}$ dan metan $\left(\mathrm{CH}_{4}\right)$ (Widodo, 2012). Konsentrasi gas metan hasil fermentasi nutrien dalam rumen menyebabkan kehilangan energi yang tidak efisien bagi ternak (Imsya et al., 2015).

Nilai VFA penting untuk diketahui sebagai gambaran sumbangan energi untuk ruminansia juga sebagai estimasi kerangka karbon dan energi (ATP) yang tersedia untuk sintesis protein mikroba rumen dengan mengoptimalkan ketersediaan $\mathrm{N}-\mathrm{NH}_{3}$. Nilai VFA dan $\mathrm{N}-\mathrm{NH}_{3}$ rumen hasil fermentasi bahan pakan oleh mikroba memberikan gambaran tingkat kelarutan karbohidrat dan protein pakan selama proses fermentasi di dalam rumen (Rudi, 2017).

Bahan pakan hasil industri pertanian mempunyai nilai nutrien yang berbeda-beda (Santoso dan Hariadi, 2009), sehingga pemberiannya sebagai pakan ruminansia perlu diperhatikan nilai fermentabilitasnya. Bahan pakan hasil samping industri pertanian memiliki kelarutan nutrienberbedabeda berdasarkan karakteristik bahan pakan dan kandungan nutriennya (Wati et al., 2012). Evaluasi nilai fermentabilitas nutrien bahan pakan hasil samping industri pertanian dibutuhkan untuk optimalisasi penggunaannya sebagai pakan atau campuran pakan ruminansia. Kombinasi bahan pakan sumber energi dan protein yang baik akan memberikan nilai pemanfaatan nutrien yang lebih baik kepada ternak atau mikroba rumen. Sinkronisasi ketersediaan energi dan protein di dalam rumen diperlukan untuk optimalisasi sintesis mikroba rumen (Sutardi, 1978). Berdasarkan pertimbangan tersebut, perlu dikaji potensi bahan pakan hasil samping industri pertanian terhadap fermentabilitas di dalam rumen secara in vitro.

\section{MATERI DAN METODE}

Materi penelitian yang digunakan adalah bahan pakan hasil samping industri pertanian, yaitu janggel jagung, kulit kopi, onggok, bungkil kedelai, bungkil kelapa sawit, bungkil kelapa, ampas tahu, cairan rumen, bahan kimia untuk analisis proksimat, bahan kimia analisis konsentrasi VFA parsial, bahan kimia analisis konsentrasi $\mathrm{N}-\mathrm{NH}_{3}$ dan bahan kimia analisis secara in vitro. Alat yang digunakan seperangkat alat gas chromatography (GC), seperangkat alat mikrodifusi Conway untuk mengukur $\mathrm{NH}_{3}$. 
Analisis Konsentrasi

\section{Propionate dan Butirat}

Pengukuran konsentrssi asam asetat, propionat, dan butirat dilakukan dengan menggunakan alat Gas Chromatography (General Laboratory Procedures, 1966) dengan metode teknik Gas Chromatography (Abdurachman dan Surayah, 2000). Jenis gas chromatography yang digunakan yaitu GC 8A, Shimadzu Corp., Kyoto, Japan dengan kolom berisi $10 \%$ SP-1200, $1 \% \quad \mathrm{H}_{3} \mathrm{PO}_{4}$ on 80/100 Cromosorb WAW. Sampel VFA parsial (asetat, propionat, dan butirat) yang digunakan berasal dari proses fermentasi secara in vitro mengikuti Tilley dan Terry, (1963) dengan modifikasi inkubasi 4 jam (Tillman et al., 1994). Konsentrasi VFA yang akan diukur dapat dilihat pada kromatogram. Konsentrasi VFA sampel dihitung dengan rumus:

VFA parsial (mM)

$$
=\left(\frac{\text { area sampel } \mathrm{x} \text { konsentrasi standar x 1000 }}{\text { area standar x BM }}\right)
$$

Keterangan :

$\mathrm{BM}$ : bobot molekul dari asetat, propionat dan butirat

\section{Mikrodifusi Conway}

Pengukuran $\mathrm{N}_{-} \mathrm{NH}_{3}$ menggunakan metode mikrodifusi Conway (Conway, 1950). Cawan Conway disterilisasi terlebih dahulu sebelum digunakan kemudian diolesi vaselin pada kedua bibirnya. Sebanyak $1 \mathrm{ml}$ supernatan ditempatkan pada salah satu sisi sekat cawan dan disisi yang lain ditempatkan 1 ml larutan $\mathrm{Na}_{2} \mathrm{CO}_{3}$ jenuh. Pada bagian tengah cawan ditempatkan $1 \mathrm{ml}$ asam borat berindikator merah metil dan brom kresolhijau. Kemudian inkubasi dengan caracawan ditutup rapat sehingga anaerob. Larutan $\mathrm{Na}_{2} \mathrm{CO}_{3}$ jenuh dicampurkan dengan supernatan dengan cara menggoyangkan secara perlahan-lahan. Kemudian diinkubasi selama 24 jam pada suhu kamar. Setelah selesai inkubasi, tutup cawan dibuka kemudian asam borat dititrasi dengan 0,0055 $\mathrm{N}_{2} \mathrm{SO}_{4}$ dari warna biru sampai menjadi merah muda.
Perhitungan untuk konsentrasi $\mathrm{N}-\mathrm{NH}_{3}$ menggunakan rumus:

$\mathrm{N}-\mathrm{NH}_{3}(\mathrm{mM})=\mathrm{ml} \mathrm{H}_{2} \mathrm{SO}_{4} \times \mathrm{N} \mathrm{H}_{2} \mathrm{SO}_{4} \times 1000$

\section{Produksi Adenosine Trifosfte (ATP)}

Pengukuran ATP dihitung berdasarkan kandungan asetat, propionate dan butirat hasil fermentasi oleh mikrobia rumen dari (Owen dan Goetsch, 1988 : Orskov dan Ryle 1990). Adapun rumus perhitungan yang digunakan yaitu :

$\operatorname{ATP}(m M)=2,5 \mathrm{~A}+2,75 \mathrm{P}+3,5 \mathrm{~B}$

Keterangan :

$\mathrm{A}=$ kandungan asetat $(\mathrm{mM})$

$\mathrm{P} \quad=$ kandungan propionate $(\mathrm{mM})$

$\mathrm{B}=$ kandunganbutirat $(\mathrm{mM})$

\section{Analisis Konsentrasi Metan $\left(\mathrm{CH}_{4}\right)$}

Konsentrasi metan dihitung berdasarkan kandungan asetat, propionate dan butirat hasil fermentasi oleh mikrobia rumen dari (Owen dan Goetsch, 1988 :Orskov dan Ryle 1990). Adapun rumus yang digunakan yaitu :

$\operatorname{Metan}(\mathrm{mM})=0,5 \mathrm{~A}-0,25 \mathrm{P}+0,5 \mathrm{~B}$

Keterangan :

A : mol asetat

$\mathrm{P} \quad$ : mol propionat

B : mol butirat

\section{Analisis data}

Data yang peroleh dianalisis ragam pada taraf 5\% dan dilanjutkan dengan uji Duncans multiple range test (Harjosuwono et al., 2011).

\section{HASIL DAN PEMBAHASAN}

Komposisi kimia bahan pakan hasil samping industri pertanian pada penelitian ini disajikan pada Tabel 1. Bahan pakan onggok mengandung karbohidrat $89,68 \%$, janggel jagung $83,91 \%$ dan kulit kopi $83,17 \%$ lebih tinggi dibandingkan bungkil kedelai $56,99 \%$, ampas tahu $63,31 \%$, bungkil kelapa $73,60 \%$ dan bungkil kelapa sawit 76,97\%. Kandungan karbohidrat bahan pakan yang tinggi cenderung menghasilkan konsentrasi VFA yang tinggi. 
Tabel 1. Komposisi kimia bahan pakan hasil samping industri pertanian

\begin{tabular}{|c|c|c|c|c|c|c|c|}
\hline \multirow{3}{*}{$\begin{array}{l}\text { Kandungan } \\
\text { Nutrien }\end{array}$} & \multicolumn{7}{|c|}{ Bahan Pakan } \\
\hline & \multicolumn{7}{|c|}{ |---------------------------------------\%"----------------------------------------- } \\
\hline & JJG & KLK & OGK & BKK & BKS & BKL & ATH \\
\hline BK & 89,83 & 92,35 & 88,56 & 89,47 & 91,13 & 85,42 & 10,73 \\
\hline PK & 6,96 & 10,28 & 5,92 & 38,17 & 15,46 & 20,50 & 15,81 \\
\hline LK & 4,77 & 3,19 & 0,26 & 1,54 & 4,21 & 2,21 & 3,60 \\
\hline $\mathrm{KH}$ & 83,91 & 83,17 & 89,68 & 56,99 & 76,97 & 73,60 & 63,31 \\
\hline NDF & 53,62 & 67,07 & 11,46 & 35,09 & 62,61 & 52,96 & 22,24 \\
\hline $\mathrm{ADF}$ & 33,19 & 35,16 & 8,26 & 13,54 & 31,25 & 28,03 & 11,21 \\
\hline NFC & 30,29 & 16,10 & 78,22 & 21,90 & 14,36 & 20,64 & 41,07 \\
\hline Selulosa & 22,61 & 19,08 & 6,02 & 8,83 & 18,93 & 4,86 & 8,41 \\
\hline Lignin & 10,13 & 14,42 & 1,62 & 2,58 & 11,43 & 22,42 & 2,11 \\
\hline $\mathrm{Abu}$ & 4,36 & 3,36 & 4,14 & 3,30 & 3,36 & 3,69 & 4,34 \\
\hline
\end{tabular}

Keterangan: JJG= janggel jagung, KLK = kulit kopi, OGK = onggok, BKK= bungkil kedelai, BKS = bungkil kelapa sawit, $\mathrm{BKL}=$ bungkil kelapa, $\mathrm{ATH}=$ ampas tahu, non fiber carbohydrate(NFC), netral detergent fiber(NDF), acid detergent fiber (ADF).

Konsentrasi VFA dipengaruhi fermentasi karbohidrat didalam rumen. Konsentrasi VFA dibentuk dari proses perombakan serat kasar oleh mikroba, sehingga kandungan serat kasar pada pakan berpengaruh pada nilai VFA (Hapsari et al., 2018). Kandungan NDF bahan pakan kulit kopi tertinggi $67,07 \%$, sedangkan onggok terendah $11,46 \%$. Kandungan NDF bahan pakan kulit kopi yang tinggi menghasilkan konsentrasi metan yang tinggi. Tingginya konsentrasi metan dipengaruhi tingginya nilai NDF bahan pakan (Santoso dan Hariadi, 2009).

Kandungan protein kasar bahan pakan bungkil kedelai tertinggi 38,17\%, sedangkan onggok terendah 5,92\%. Kandungan protein kasar bahan pakan yang tinggi cenderung menghasilkan konsentrasi $\mathrm{N}-\mathrm{NH}_{3}$ tinggi. Wahyuni et al. (2009) melaporkan bahwa protein bahan pakan turut mempengaruhi konsentrasi amonia yang dihasilkan didalam rumen. Konsentrasi N$\mathrm{NH}_{3}$ dipengaruhi oleh kandungan bahan pakan sumber protein sedangkan ATP dari hasil fermentasi karbohidrat. Faktor-faktor yang mempengaruhi konsentrasi $\mathrm{N}-\mathrm{NH}_{3}$ adalah kandungan protein pakan, degradasi protein, dan sumber energi dan proporsi karbohidrat terlarut menjadi energi ATP (Prayitno et al., 2018).

\section{Konsentrasi Asetat, Propionat dan Butirat}

Hasil analisis ragam menunjukkan konsentrasi asetat, propionat dan butirat berbeda nyata $(\mathrm{P}<0,05)$ diantara perlakuan bahan pakan hasil samping industri pertanian. Nilai asetat yang berbeda antara bahan pakan hasil samping industri pertanian dipengaruhi oleh kandungan nutrien bahan pakan yang berbeda terutama selulosa,dan NDF (Tabel 1). Santoso dan Hariadi (2009) menyatakan bahwa kandungan NDF bahan pakan hasil samping industri pertanian menghasilkan VFA yang berbeda. Komponen konsentrasi VFA (asetat, propionat, butirat) terbentuk dari hasil fermentasi karbohidrat berupa selulosa, hemiselulosa, gula, pektin, fruktan dan pati (Van Soest, 1994).

Uji Duncan menunjukkan konsentrasi asam asetat pada bahan pakan janggel jagung berbeda nyata $(\mathrm{P}<0,05)$, tetapi tidak berbeda nyata $(\mathrm{P}>0,05)$ terhadap bungkil kepala, ampas tahu, bungkil kedelai, onggok, bungkil kelapa sawit dan kulit kopi. Perbedaan yang nyata antara bahan pakan karena kandungan serat selulosa dari bahan janggel jagung tinggi dibanding dengan bahan pakan kulit kopi, bungkil kelapa sawit, bungkil kelapa, bungkil kedelai, onggok dan ampas tahu (Tabel 1). 
Tabel 2. Konsentrasi asetat, propionat, butirat, TVFA, $\mathrm{CH}_{4}$, dan $\mathrm{N}-\mathrm{NH}_{3}$

\begin{tabular}{|c|c|c|c|c|c|c|}
\hline \multirow[b]{2}{*}{ Perlakuan } & $\mathrm{C}_{2}$ & $\mathrm{C}_{3}$ & $\mathrm{C}_{4}$ & TVFA & $\mathrm{CH}_{4}$ & $\mathrm{~N}-\mathrm{NH}_{3}$ \\
\hline & \multicolumn{6}{|c|}{----------------------------------------(mM) --------------------------------------------- } \\
\hline JJG & $71,06^{\mathrm{a}}$ & $52,51^{\mathrm{a}}$ & $33,16^{\mathrm{a}}$ & $156,73^{\mathrm{a}}$ & $38,98^{\mathrm{a}}$ & $1.89^{\mathrm{f}}$ \\
\hline KLK & $34,30^{\mathrm{d}}$ & $25,33^{\mathrm{e}}$ & $24,64^{\mathrm{e}}$ & $84,27^{\mathrm{d}}$ & $23,14^{\mathrm{e}}$ & $3,28^{\mathrm{e}}$ \\
\hline OGK & $41,82^{\mathrm{c}}$ & $30,12^{\mathrm{d}}$ & $26,12^{\mathrm{cd}}$ & $98,07^{\mathrm{c}}$ & $26,44^{\mathrm{cd}}$ & $3,17^{\mathrm{e}}$ \\
\hline BKK & $42,62^{c}$ & $36,68^{c}$ & $25,80^{\mathrm{cd}}$ & $104,73^{\mathrm{c}}$ & $24,86^{\mathrm{de}}$ & $6,03^{\mathrm{ab}}$ \\
\hline BKS & $34,39^{\mathrm{d}}$ & $26,61^{\mathrm{e}}$ & $24,90^{\mathrm{e}}$ & $85,90^{\mathrm{d}}$ & $22,99^{\mathrm{e}}$ & $3,83^{\mathrm{d}}$ \\
\hline BKL & $51,48^{b}$ & $43,45^{\mathrm{b}}$ & $28,84^{\mathrm{b}}$ & $123,77^{b}$ & $29,30^{b}$ & $7,50^{\mathrm{a}}$ \\
\hline ATH & $52,60^{\mathrm{b}}$ & $46,43^{b}$ & $27,51^{b c}$ & $126,53^{b}$ & $28,45^{\mathrm{bc}}$ & $4,68^{\mathrm{c}}$ \\
\hline
\end{tabular}

Keterangan: Superskrip yang berbeda pada kolom yang sama menunjukkan berbeda nyata $(\mathrm{P}<0,05)$. JJG $=$ janggel jagung, $\mathrm{KLK}=$ kulit kopi, OGK = onggok, $\mathrm{BKK}=$ bungkil kedelai, $\mathrm{BKS}=$ bungkil kelapa sawit, $\mathrm{BKL}=$ bungkil kelapa, $\mathrm{ATH}=$ ampas tahu

Asam butirat memiliki hubungan erat dengan asam asetat karena keduanya merupakan asam yang bersifat non glukogenik. Nilai rata-rata asam butirat (Tabel 2) menunjukkan berbeda nyata $(\mathrm{P}<0,05)$. Harfiah (2009) bahwa fraksi serat sering terdapat dalam bentuk berikatan dengan lignin sehingga menjadi sulit dicerna oleh mikroba rumen. Sandi et al. (2013) bahwa tingginya kandungan lignin pada bahan pakan sebagai komponen penyusun serat akan mengakibatkan mikroba sulit mendegradasi bahan pakan di dalam rumen.

Asam propionat merupakan asam yang bersifat glukogenik. Nilai rata-rata asam propionat (Tabel 2) menunjukkan berbeda nyata $(\mathrm{P}<0,05)$. Nilai propionat yang berbeda dipengaruhi oleh kandungan nutrien bahan pakan terutama karbohidrat $(\mathrm{KH})$ yaitu pati dan pektin (Tabel 1). Uji Duncan menunjukkan bahwa konsentrasi asam propionat pada bahan pakan janggel jagung berbeda nyata $(\mathrm{P}<0,05)$, tetapi tidak berbeda nyata $(\mathrm{P}>0,05)$ terhadap kulit kopi, onggok, bungkil kedelai, bungkil kelapa sawit, bungkil kelapa dan ampas tahu. Fenomena ini terjadi karena kandungan karbohidrat non struktural seperti pati dan pektin pada bahan pakan janggel jagung yang cenderung tinggi. Konsentrasi VFA parsial dipengaruhi oleh komposisi nutrien bahan pakan. Konsentrasi asam asetat, propionat dan butirat hasil dari fermentasi bahan pakanyang menggambarkan tingkat kelarutan karbohidrat dan protein selama proses fermentasi (Wahyuni et al., 2014).
Bata dan Hidayat (2010) menyatakan bahwa tinggi rendahnya konsentrasi VFA mengambarkan mudah tidaknya karbohidrat difermentasi, semakin tinggi VFA maka semakin tinggi karbohidrat dan protein tersebut difermentasi di dalam rumen. Kandungan bahan pakan hasil samping industri pertanian yang mengandung karbohidrat mudah difermentasi cenderung mengahsilkan asam propionat tinggi (Hilali et al., 2018). Asam asetat merupakan senyawa nonglukogenik dan hampir semua mampu dioksidasi. Muchlas et al. (2013) bahwa akibat proses oksidasi menimbulkan heat increament yang tinggi sehingga nilai efisiensinya rendah. Sebaliknya propionat merupakan senyawa sugar precursor merupakan glukogenik utama.

\section{Konsentrasi Metan $\left(\mathrm{CH}_{4}\right)$}

Metan merupakan hasil dari fermentasi karbohidrat yang dilakukan oleh bakteri penghasil metan (Imanda et al., 2016). Uji Duncan menunjukkan bahwa konsentrasi metan pada bahan pakan janggel jagung berbeda nyata $(\mathrm{P}<0,05)$, namun tidak berbeda nyata $(\mathrm{P}>0,05)$ terhadap kulit kopi, onggok, bungkil kedelai, bungkil kelapa sawit, bungkil kelapa dan ampas tahu.Bahan pakan hasil samping industri pertanian yang berbeda tersebut dipengaruhi oleh kandungan nutrien bahan pakan terutama kandungan selulosa pakan (Tabel 1). Santoso dan Hariadi (2009) menyatakan bahwa faktor serat selulosa pakan industri pertanian turut mempengaruhi nilai konsentrasi metan 
yang dihasilkan saat difermentasi didalam rumen.

Bahan pakan kulit kopi menghasilkan konsentrasi metan yang lebih tinggi dibanding bahan pakan lainnya. Konsentrasi metan yang tinggi pada kulit kopi dipengaruhi oleh kandungan nutrien terutama selulosa yang tinggi dan tingginya konsentrasi VFA (Tabel 2). Ramandhani et al. (2018) menyatakan bahwa meningkatnya metan dipengaruhi oleh tingginya kandungan serat selulosa bahan pakan. Fonemena tersebut didukung oleh konsentrasi asam asetat dan asam butirat yang tinggi pada bahan pakan janggel jagung (Tabel 2). Tingginya kandungan fraksi selulosa cenderung meningkatkan konsentrasi metan melalui perubahan proporsi asam lemak astiri kearah peningkatan proporsi asam asetat yang memproduksi gas hidrogen sebagai substrat utama pada reaksi metanogenesis (Jayanegara et al., 2008 ; Trotta et al., 2018).

\section{Konsentrasi N-NH}

Konsentrasi $\mathrm{N}^{-\mathrm{NH}_{3}}$ mengambarkan jumlah protein pakan yang dapat difermentasikan didalam rumen dan nilainya sangat dipengaruhi oleh kemampuan mikroba rumen dalam mendegradasi protein pakan dan mudah tidaknya protein pakan didegradasi (Rudi, 2017). Berdasarkan analisis ragam menunjukkan bahwa konsentrasi $\mathrm{N}^{-\mathrm{NH}_{3}}$ dari perlakuan bahan pakan bungkil kelapa dan bungkil kedelai berbeda nyata $(\mathrm{P}<0,05)$. Tinggi rendahnya konsentrasi $\mathrm{N}^{-\mathrm{NH}_{3}}$ dipengaruhi oleh kandungan nutrien bahan pakan terutama protein kasar (Tabel 1). Konsentrasi $\mathrm{N}-\mathrm{NH}_{3}$ dipengaruhi oleh jumlah degradasi protein kasar dalam rumen dan pemanfaatan $\mathrm{N}-\mathrm{NH}_{3}$ oleh mikroba rumen untuk pembentukan protein mikroba (McDonald et al.,2010).

Uji Duncan menunjukkan konsentrasi $\mathrm{N}-\mathrm{NH}_{3}$ pada bahan pakan bungkil kelapa dan bungkil kedelai berbeda nyata $(\mathrm{P}<0,05)$, namun tidak berbeda nyata $(\mathrm{P}>0,05)$ terhadap bahan pakan kulit kopi, ampas tahu, bungkil kelapa sawit dan onggok. Konsentrasi $\mathrm{N}-\mathrm{NH}_{3}$ yang berbeda adalah bungkil kelapa dan bungkil kedalai disebabkan oleh kandungan nutien terutama protein yang tinggi. Semakin tinggi degradasi protein dalam rumen akan meningkatkan konsentrasi $\mathrm{N}-\mathrm{NH}_{3}$, sebaliknya dengan semakin rendahnya degradasi protein dalam rumen, maka konsentrasi $\mathrm{N}-\mathrm{NH}_{3}$ rumen menjadi menurun.

Rudi (2017) menyatakan bahwa konsentrasi $\mathrm{N}^{-\mathrm{NH}_{3}}$ dipengaruhi oleh kandungan protein, tingkat degradasi protein dan kelarutan protein bahan pakan. Tingkat hidrolisis protein pakan tergantung dari daya larutnya yang berkaitan erat dengan konsentrasi amonia (Arora, 1995). Konsentrasi N-NH${ }_{3}$ hasil penelitian (Tabel 2) sudah mampu untuk mendukung sintesis protein mikroba didalam rumen kecuali pada bahan pakan janggel jagung. Menurut Rahmadi et al. (2010) melaporkan bahwa konsentrasi amonia optimum dalam mendukung sintesis protein mikroba antara $3,57-7,14 \mathrm{mM}$. Sintesis dan aktivitas mikroba rumen tergantung pada ketersediaan energi (ATP) yang tersedia. Hindratiningrum et al. (2011), bahwa apabila konsentrasi N$\mathrm{NH}_{3}$ dalam cairan rumen rendah, maka fiksasi amonia akan membutuhkan ATP, sedangkan konsentrasi $\mathrm{N}-\mathrm{NH}_{3}$ cukup tinggi, maka tanpa memerlukan ATP amonia langsung terinkorporasi ke dalam asam amino mikroba.

\section{KESIMPULAN}

Bahan pakan hasil samping industri pertanian janggel jagung menghasilkan konsentrasi asetat, propionat, butirat dan adenosin triphosphate tertinggi. Namun, janggel jagung juga menghasilkan konsentrasi metan tertinggi. Konsentrasi amonia tertinggi diperoleh pada bungkil kelapa dan ikuti bungkil kedelai. Kombinasi pokok pakan sumber energi berupa janggel jagung dan sumber protein dari bungkil kelapa dan bungkil kedelai sangat diperlukan untuk memberikan nilai pemanfaatan nutrien yang lebih baik kepada ternak atau mikroba rumen. 


\section{DAFTAR PUSTAKA}

Abdurachman dan A. Surayah. 2000. Studi Banding Analisis VFA Total dengan Metode Destilasi dan Kromatografi Gas. Temu Teknis Fungsional Non Peneliti. Balai Penelitian Ternak. Bogor.

Arora, S. P. 1995. Pencernaan Mikrobia pada Ruminansia. Gadjah Mada University Press, Yogyakarta (Diterjemahkan oleh R. Murwani).

Bata, M., dan Hidayat, N. 2010. penambahan molases untuk meningkatkan kualitas amoniasi jerami padi dan pengaruhnya terhadap produk fermentasi rumen secara in vitro. Agripet, 10 (2): 27-33.

Conway, E. J. 1950. Microdiffusion Analysis and Volumetric Error. $3^{\text {rd }}$ Ed. Crostay Loskwood and Sows. Ltd. London.

Fachiroh, L., B. Prasetiyono, W. H. E., dan A. Subrata. 2012. Kadar protein dan urea darah kambing perah Peranakan Etawa yang diberi wafer pakan komplit berbasis limbah agroindustri dengan suplementasi protein terproteksi. Anim. Agri J. 1(1): 443-451.

General Laboratory Prosedures. 1966. Department of Dairy Science. University of Wisconsin, Madison.

Hapsari, N. S., D, W., Harjanti dan A. Muktiani. 2018. Fermentabilitas Pakan dengan Imbuhan Ekstrak Daun Babadotan (Ageratum conyzoides) dan Jahe (Zingiber officinale) pada Sapi Perah secara In Vitro. Agripet 18 (1):19.

Harfiah. 2009. Peningkatan kualitas pakan berserat dengan perlakuan alkali amoniasi dan fermentasi dengan mikroba selulolitik dan lignolitik. J. Sains dan Teknologi, 9 (2): 150 - 156.
Harjosuwono, B. A., Arnata, I. W. dan G. A. K. D. Puspawati. 2011. Rancangan Percobaan Teori, Aplikasi SPSS dan Excel. Malang: Lintas Kata Publishing.

Hilali. M., B. Rischkowsky, L. Iniguez, H Mayer, and M. Screiner. 2018. Changes in the milk fatty acid profile of awassi sheep in response to supplementation with agra-industrial by-products. J. Small Ruminant Research. 166: 93-100.

Hindratiningrum, N., Bata, M., dan Santosa, S. A. 2011. Produk fermentasi rumen dan produksi protein mikroba sapi lokal yang diberi pakan jerami amoniasi dan beberapa bahan pakan sumber energi. Agripet. 11 (2): 29-34.

Imanda, S., Y., Effendi, Sihono dan I., Sugoro. 2016. Evaluasi in vitro silase sinambung sorgum varietas Samurai 2 yang mengandung probiotik BIOS K2 dalam cairan rumen kerbau. J. Ilmiah Aplikasi Isotop dan Radiasi. 12 (1): 112.

Imsya, A., Muhakka, dan F.,Yossi. 2015. Evaluasi konsentrasi VFA parsial dan estimasi produksi gas metan bahan pakan dari limbah pertanian danrumput rawa secara in vitro. Proseding Seminar Nasional Lahan Suboptimal, Palembang. 8-9 Oktober 2015. ISBN: 979-587-580-9.

Jayanegara, A., A. Sofyan, H.P.S. Makkar dan K. Becker. 2009. Kinetika produksi gas, kecernaan bahan organik dan produksi gas metana in vitro pada hay jerami yang disuplementasi hijauan mengandung tanin. Media Peternakan. 32 (2): 120-129.

McDonald, P., R. A., J.F.D. Edwards. Greenhalg, CA., Morgan. 2010. Animal Nutrition ( $7^{\text {th }}$ Ed.). London and New York (US): Longman. 
Muchlas, M., Kusmartono dan Marjuki. 2014. Pengaruh penambahan daun pohon terhadap kadar VFA dan kecernaan secara in vitro ransum berbasis ketela pohon. J. Ilmu-ilmu Peternakan 24(2): 8-19.

Orskov, E. R. dan Ryle. 1990. Energy Nutrition in Ruminant. Elsevier Applied Science. London.

Owen, F. N., A. L., Goetsch,. 1988. Ruminal Fermentation. Dalam: The Ruminant Animal: Digestive Physiology and Nutrition. Church. New Jersey: Prentice Hall.

Prayitno, R., S.,F. Wahyono. dan E. Pangestu. 2018. Pengaruh Suplementasi Sumber Protein Hijaun Leguminosa Terhadap Produksi Amonia dan Protein Total Ruminal Secara In vitro. Jurnal Peternakan Indonesia. 20 (2): 116-123.

Purbowati, E., C.I. Sutrisno, E. Baliarti, S.P.S. Budhi, dan W. Lestariana. 2007. Penampilan produksi domba local jantan dengan pakan kompilt dari berbagai limbah pertaniaan dan agroindustri. Seminar Nasional Kebangkitan Nasional, Semarang. 20 Mei 2009:130 - 138.

Rahmadi, D., A. Muktiani, E. Pangestu, J. Achmadi, M. Christiyanto, Sunarso, Surono dan Surahmanto. 2010. Ruminologi Dasar. Jurusan Nutrisi dan Makanan Ternak Fakultas Peternakan Universitas Diponegoro. Sekawan, Semarang.

Ramandhani, A., D.W.Harjanti, dan A. Muktiani. 2018. Pengaruh pemberian ekstrak daun papaya (Carica papaya Linn) dan kunyit (Curcuma domestica) terhadap fermentabilitas rumen sapi perah in vitro. J. Ilmu-Ilmu Peternakan. 28 (1): 73-83.
Rudi. 2017. Kinetika Degradasi Bahan Kering Beberapa Bahan Pakan Ruminansia Serta Korelasinya dengan Kecernaan Nutrien secara In Vitro. Disertasi. Institut Pertanian Bogor.

Sandi, Y. O., S. Rahayu, W. dan Suryapratama. 2013. Upaya peningkatan kualitas kulit singkong melalui fermentasi menggunakan Leuconostoc mesenteroides pengaruhnya terhadap kecernaan bahan kering dan bahan organik secara in vitro. Jurnal Ilmiah Peternakan. 1(1): 99-108.

Santoso, B and B. T. Hariadi .2009. Evaluation of nutritive value and in vitromethane production of feedstuffs from agricultural and food industry by products. J. Indonesia Tropical Animal Agriculture. 34 (3): 189-195.

Tilley, J. M. A. dan R. A. Terry. 1963. A two stage technique for the in vitro digestion of forage crops. Journal of the British Grassland Society. 18:104111.

Tillman, A. D., H. Hartadi, S. Reksohadiprodjo, S. Prawirokusumo dan S. Lebdosoekojo. 1994. Ilmu Makanan Ternak Dasar. Gadjah Mada University Press. Yogyakarta.

Trotta, R. J., J. L., Klotz. and D. L Harmon. 2018. Effects of source and level of dietary energy supplementation on in vitro digestibility and mehane production from tall fescue-based diets. J. Animal Feed Science and Technology. 242: 41-47.

Van Houtert, M.F.J. 1993. The production and metabolism of volatile fatty acids by ruminants fed roughages: a review. Animal Feed Science and Technology. 43: $189-225$. 
Van Soest, P.J. 1994. Nutritional Ecology of the Ruminant. 2nd. Edition. Cornell University Press, Ithaca and London.

Vlaming, J. B. 2008. Quantifying Variation in Estimated Methane Emission from Ruminants Using the SF6 Tracer Fechnique. A Thesis of Doctor of Phylosophy in Animal Science. Massey University, Palmerston North, New Zealand.

Wahyuni, I. M., A. Muktiani, dan M. Christiyanto. 2014. Kecernaan bahan kering dan bahan organik dan degradabilitas serat pada pakan yang disuplementasi tanin dan saponin. Agripet. 2 (2): 115-124.

Wati, N. E., J., Achmadi. dan E. Pangestu. 2012. Degradasi nutrien bahan pakan limbah pertanian dalam rumen kambing secara in sacco. Anim. Agri J. 1 (1): $485-498$.

Widodo, F., Wahyono, dan Sutrisno. 2012. Kecernaan bahan kering, kecernaan bahan organik, produksi VFA dan NH3 pakan komplit dengan level jerami padi berbeda secara in vitro. Anim. Agric. J. 1(1): 215-230. 